\title{
Herbicide Screening For Four Grain Legumes in Puerto Rico'
}

\begin{abstract}
Guillermo Riveros ${ }^{2}$
ABSTRACT

The performance of 19 herbicides in 50 treatments was evaluated in terms of their selectivity to soybean, pigeon pea, cowpea and field beans, and of their effect upon the weed populations of three localities in Puerto Rico represented by three of the substations of the Agricultural Experiment Station.

Although the majority of the products tested were selective to the four crops at the three sites, some were more toxic to certain crops or in given localities. Fluchloralin was more toxic to soybeans and field beans at Lajas and to pigeon pea in Isabela and Fortuna. Cowpeas and field beans were very sensitive to metribuzin, while soybeans and pigeon peas were more tolerant. Toxicity of metribuzin to soybeans and pigeon peas was more pronounced at higher rates and in the lightest soil. Oryzalin was more toxic to pigeon pea in Isabela and to cowpea in Fortuna. Profluralin was more toxic in Lajas and prometryn in Fortuna than in the other sites. U 27267 was more toxic when incorporated than when applied to the surface. There were differences in the degree of weed control among products, rates and localities. The differences among localities were related to variations in soil characteristics and weed populations. The results strongly support the importance of simultaneously considering the crop, the weed population and soil characteristics before recommending herbicides.
\end{abstract}

\section{INTRODUCTION}

Weed control is essential for successful crop production, especially in the tropics, where climatic conditions favor diversity, high populations and vigorous growth of weeds. Although effective and economical weed control can be achieved only by a combination of practices selected for specific conditions, chemical control should be considered an integral part of any weed control scheme.

The proper choice of the herbicide or herbicides, to be used in a given set of conditions, depends largely on the availability of compounds to select from. Since there are not many herbicides registered for use in the production of the most important legumes in grown Puerto Rico, namely pigeon pea (Cajanus cajan), field beans (Phaseolus vulgaris L.), cowpeas (Vigna unguiculata L.) Walp. and for a potential successful production of soybeans (Glycine max (L.) Merrill), the present work was undertaken in order to evaluate several herbicides for their selectivity toward these crops in three localities Puerto Rico and to assess their general effects on the weed populations in the three areas. The information obtained may be used as a base for further detailed studies.

\footnotetext{
${ }^{1}$ Manuscript submitted to Editorial Board March 10, 1980.

${ }^{2}$ Weed Scientist INTSOY and Associate Professor, Department of Crop Protection, College of Agricultural Sciences, University of Puerto Rico, Mayagüez Campus.
} 


\section{MATERIALS AND METHODS}

Field bean cultivars Bonita and Naranjito; cowpea cultivars Cabecinegro and Producer; pigeon pea cultivar Kaki and promising breeding lines numbers 7, 12, 6968, 64-2B, 64-16A-1 and 64-21B; and soybean cultivars Hardee, Williams, Davis, Hampton, Jupiter and Kanrich, were planted by hand in rows $1 \mathrm{~m}$ apart.

Plantings were made at Isabela, Fortuna and Lajas substations January 24, February 14th, and February 21st, 1975, respectively. These three localities differ in several soil characteristics, such as infiltration rate (6), texture, organic matter content and cation exchange capacity (CEC), which influence the behavior of some herbicides $(3,4,5)$. Some characteristics of the soils of Isabela, Fortuna and Lajas are, respectively. CEC $140,23.0$ and $58.0 \mathrm{meq} / 100 \mathrm{~g}$; organic matter content $2.2,3.3$ and $4.2 \%$; clay $51.8,34.3$, and $65.1 \%$; sand $23.4,15.0$ and $11.1 \%$; and silt $24.8,50.7$ and $23.8 \%$.

Herbicides were selected from information gathered in the litertaure especially that of work performed in tropical areas (1,7); from the reports of the International Plant Protection Center of Oregon University (2); and from recommendations of some chemical manufacturers.

The products were applied the same day of planting, in strips $1 \mathrm{~m}$ wide in a direction perpendicular to the 17 rows of the crops. Herbicides were applied with an $\mathrm{A}-\mathrm{Z} \mathrm{CO}_{2}$ powered sprayer at a pressure of $2.1 \mathrm{~kg} / \mathrm{cm}^{2}$ fitted with 8004 fan nozzles. The spray volume was equivalent to $200 \mathrm{~L} /$ ha.

Seven products in 18 treatments were used in preplant incorporated (PPI) applications. Incorporation was performed mixing the top $5 \mathrm{~cm}$ of soil with a garden hoe. Fourteen compounds in 32 treatments were applied to the soil surface prior to emergence. Table 1 shows the products used, their chemical names, as well as the rates of application.

Seeds of soybeans were treated with a commercial Rhizobium japonicum inoculum just before planting. All crops were fertilized with an equivalent rate of $100 \mathrm{~kg} / \mathrm{h}$ a of $\mathrm{P}_{2} \mathrm{O}_{5}$. Water was applied the day following planting by overhead irrigation in Fortuna and Isabela, and by surface irrigation in Lajas.

Weed species in the three localities are listed in order of decreasing abundance:

Isabela.-Wild Poinsettia (Euphorbia heterophylla), Spanish needles (Bidens pilosa), rincosia (Rhynchosia minima), morning glory (Ipomoea tiliacea), lion's ear (Leonotis nepetifolia), goosegrass (Eleusine indica), crabgrass (Digitaria sanguinalis), broadleaf signalgrass (Brachiaria platiphylla). Weed population composition was estimated to be of about $80 \%$ broadleaf weeds and $20 \%$ grasses.

Lajas._Johnsongrass (Sorghum halepense), junglerice (Echinochloa 
TABLE 1.-Herbicides tested in a preliminary screening trial with four grain legumes in three localities of Puerto Rico, 1975

\begin{tabular}{|c|c|c|c|}
\hline Common names & Chemical names & $\begin{array}{c}\text { Time of } \\
\text { applications }\end{array}$ & $\begin{array}{c}\text { Rate } \\
\mathrm{kg} \mathrm{a.i} / \mathrm{ha}\end{array}$ \\
\hline Alachlor & 2-chloro-2,6-diethyl-N-(metoxymethyl) acetanilide & Pre & $1.5,3.0$ \\
\hline Benthiocarb & S-(4-chlorobenzyl) N,N-diethylthiocarbamate & Pre & $3.0,6.0$ \\
\hline Butralin & $\mathrm{N}$-sec-butyl-4-tert-butyl-2,6-dinitroaniline & PPI & $1.5,2.5$ \\
\hline Chloramben & 3-amino,2,5-dichlorobenzoic acid & Pre & $2.0,3.0$ \\
\hline Chlorbromuron & 30(4-bromo-3-chlorophenyl)-1-methoxy-1-methylurea & Pre & $1.12,2.24$ \\
\hline Chloroxuron & 3-(p-(p-chlorophenoxy)phenyl)-1,1-dimethylurea & Pre & $1.68,3.36$ \\
\hline DCPA & dimethyl tetrachloroterephthalate & Pre & $9.0,11.0$ \\
\hline Diphenamid & $\mathrm{N}, \mathrm{N}$-dimethyl-2,2-diphenyl acetamide & Pre & $3.36,5.60$ \\
\hline Fluchloralin & $\begin{array}{l}\mathrm{N} \text {-(propyl)-N-(2 chloroethyl)-4 (trifluoromethyl) 2,6 dinitroani- } \\
\text { line }\end{array}$ & PPI & $0.56,1.12,1.68$ \\
\hline Methazole & 2-(3,4-dichlorophenyl)-4-methyl-1,2,4-oxadiazolidine-3,5-dione & Pre & $1.68,3.36$ \\
\hline Metribuzin & 4-amino-6-ter-butyl-3(methylthio)-as-triazin--5(4H) one & Pre & $0.5,0.75,1.0$ \\
\hline Nitrofen & 2,4-dichlorophenyl p-nitrophenil ether & Pre & $2.0,4.0$ \\
\hline Oryzalin & 3,5 -dinitro $\mathrm{N}^{4}, \mathrm{~N}^{4}$-dipropyl sulfanilamide & Pre & $1.5,3.0$ \\
\hline Penoxalin & $\mathrm{N}$-(1-ethylpropyl)-3,4-dimethyl-2,6 dinitroaniline & PPI & $1.25,1.5$ \\
\hline Prometryne & 2-methylthio-4,6-bis(isopropylamino) S-triazine & Pre & $1.0,1.5$ \\
\hline Profluralin & $\begin{array}{l}\mathrm{N} \text { (propyl)- } \mathrm{N} \text {-(cylopropylmethyl)-4-(trifluoromethyl)-2,6 dini- } \\
\text { troaniline }\end{array}$ & PPI & $1.12,1.68$ \\
\hline Trifluralin & $\mathrm{N}, \mathrm{N}$-dipropyl-4-(trifluoromethyl)-2,6 dinitroaniline & PPI & $1.75,1.5$ \\
\hline $\mathrm{U} 27267$ & 3,4,5-Tribromo- $\mathrm{N}, \mathrm{N}, \mathrm{a}$-trimethylpyrazole-1-acetamide & PPI \& Pre & $0.84,1.68,3.36$ \\
\hline VEL 5052 & not available & PPI \& Pre & $\begin{array}{l}0.5,1.0,2.0 \\
4.0\end{array}$ \\
\hline
\end{tabular}

${ }^{1}$ Pre $=$ preemergence; $\mathrm{PPI}=$ preplant incorporated 
colonum), scarletbean (Phaseolus lathyroides), Euphorbia heterophylla, Ipomoea tiliacea, pigweed (Amaranthus dubius), common purslane (Portulaca oleracea). In this locality grasses were dominant over broadleaf weeds at a proportion of about $80 \%$ to $20 \%$.

Fortuna.-Amaranthus dubius, Portulaca oleracea, caltrop (Kalstroemia maxima), Echinochloa colonum, Digitaria sanguinalis. Weed population was approximately 50\% grasses and 50\% broadleaves.

Phytotoxicity evaluations were performed for each cultivar at 14 and 28 days after the application of the treatments by means of a zero to ten rating scale in which zero represents no injury, and ten complete kill.

Efficacy was determined at 30 and 60 days after herbicide application by comparing the percent control of grasses and broadleaf weeds achieved in each treated plot with that of the unweeded control. The rating scale used in this study is indicated as follows: 0-10, very poor; 11-30, poor; 3150, deficient; 51-65, moderate; 66-70, satisfactory; 71-80, good; 81-90, very good; and $91-100$, excellent.

\section{RESULTS}

\section{PHYTOTOXICITY}

Since obvious differences in susceptibility among cultivars were not observed, the toxicity ratings of the cultivars of each crop are grouped together.

Table 2 shows the injury ratings of some of the products at the higher rates used. Most of the herbicides tested were selective to the four grain legumes with the exception of metribuzin. This compound, even at the rate of $0.5^{3}$, was very toxic to cowpeas and field beans, especially in Fortuna and Isabela; at the same rate it was also toxic to soybeans only in Fortuna. Pigeon pea was not injured in any locality by this rate of metribuzin. An increase of the rate of metribuzin to 0.75 caused more pronounced phytotoxicity to soybeans and pigeon peas in Fortuna, but not in Isabela and Lajas. At the rate of 1.0 metribuzin was selective for pigeon peas in Lajas and Isabela and to soybeans only in Isabela.

U 27267 was toxic only at the highest rate (3.36). Applied as a preplant incorporated treatment, it caused pronounced stunting to soybeans and field beans; only light toxicity was observed in pigeon peas and cowpeas at 14 days at Isabela. At Fortuna soybeans and pigeon peas exhibited light symptoms of toxicity. When applied as preemergent, moderate toxicity was evident in cowpeas at Fortuna and in pigeon peas at Isabela. At Lajas toxicity was light for all crops. Symptoms were more pronounced at 28 days, especially with the preplant incorporated application at

${ }^{3}$ Numbers following chemical names represent the rate applied in kilograms of active ingredient per hectare ( $\mathrm{kg}$ a.i/ha). 
TABLE 2.-Injury scores ${ }^{1}$ of selected herbicide treatments to four grain legumes ${ }^{2}$ in three localities of Puerto Rico

\begin{tabular}{|c|c|c|c|c|c|c|c|c|c|c|c|c|c|c|}
\hline \multirow{2}{*}{ Herbicide } & \multirow{2}{*}{$\begin{array}{c}\text { Rate } \mathrm{Kg} \text { a.i/ } \\
\text { ha }\end{array}$} & \multirow{2}{*}{$\begin{array}{l}\text { Time of ap- } \\
\text { plication }\end{array}$} & \multicolumn{4}{|c|}{ Lajas } & \multicolumn{4}{|c|}{ Isabela } & \multicolumn{4}{|c|}{ Fortuna } \\
\hline & & & $\mathrm{SB}$ & PP & C.P. & $\mathrm{FB}$ & $\mathrm{SB}$ & PP & $\mathrm{CP}$ & FB & $\mathrm{SB}$ & $\mathrm{PP}$ & $\mathrm{CP}$ & $\mathrm{FB}$ \\
\hline Fluchloralin & 1.68 & PPI & 3.2 & 1.1 & 1.0 & 2.0 & 1.0 & 2.4 & 1.5 & 1.0 & 0.8 & 2.3 & 0.5 & 0.0 \\
\hline Metribuzin & 0.50 & Pre & 0.3 & 0.1 & 7.0 & 7.0 & 0.5 & 0.0 & 6.5 & 8.5 & 3.7 & 1.3 & 10.0 & 10.0 \\
\hline Metribuzin & 0.75 & Pre & 1.2 & 0.9 & 10.0 & 10.0 & 1.0 & 0.3 & 6.5 & 8.5 & 5.7 & 3.3 & 10.0 & 10.0 \\
\hline Metribuzin & 1.00 & Pre & 1.7 & 1.7 & 10.0 & 10.0 & 3.0 & 0.7 & 8.0 & 9.0 & 6.0 & 3.5 & 10.0 & 10.0 \\
\hline Oryzalin & 3.0 & Pre & 1.7 & 1.3 & 1.5 & 0.0 & 2.3 & 4.3 & 2.5 & 0.0 & 0.5 & - & 4.0 & 2.5 \\
\hline Profluralin & 1.68 & PPI & 2.5 & 1.6 & 2.5 & 3.0 & 1.3 & 0.4 & 1.5 & 1.0 & 2.7 & 1.0 & 0.0 & 0.0 \\
\hline Prometryn & 1.5 & Pre & 2.3 & 0.0 & 0.0 & 3.5 & 0.3 & 1.4 & 0.5 & 5.0 & 2.8 & - & 4.0 & 3.5 \\
\hline U 27267 & 3.36 & PPI & 2.0 & 2.5 & 1.5 & 2.0 & 4.0 & 2.4 & 1.5 & 3.5 & 3.3 & 2.6 & 0.5 & 1.5 \\
\hline U 27267 & 3.36 & Pre & 2.0 & 3.4 & 2.5 & 3.0 & 0.8 & 4.1 & 1.5 & 2.5 & 0.8 & 1.9 & 4.0 & 1.0 \\
\hline
\end{tabular}

${ }^{1}$ Mean values of the scores of all the cultivars of each crop, taken 2 weeks after the applications.

${ }^{2} \mathrm{SB}=$ soybeans; $\mathrm{PP}=$ pigeon peas; $\mathrm{CP}=$ cowpeas; $\mathrm{FB}=$ field beans. 
Isabela. Pigeon peas seem to be the most sensitive crop to this chemical. In general, this compound seems to be more toxic when incorporated than when surface applied.

Oryzalin toxicity at 3.0 was moderate to pigeon peas, light to soybeans and cowpeas at Isabela and none to field beans. At Fortuna its toxicity was moderate to cowpeas and light to field beans. At Lajas the symptoms were insignificant for all crops. Symptoms persisted at 28 days, and frequently they were more pronounced than at 14 days.

Prometryn at 1.5 was moderately toxic to field beans at Isabela and mildly toxic at Lajas and at Fortuna. Cowpeas exhibited pronounced toxicity symptoms to prometryn only at Fortuna; soybeans showed light symptoms at Fortuna and at Lajas.

Although the five dinitroanilines included in the trials were selective to the four crops, there were some differences in the degree of toxicity caused by some of them. In general, symptoms were more frequent in plots treated with fluchloralin, penoxalin and profluralin than those treated with butralin or trifluralin.

\section{WEED CONTROL}

Table 3 shows that there were differences in the efficacy of the various preplant incorporated treatments to control weeds, and also in the persistence of their effects.

Best control of grasses at 30 days was observed in the plots treated with fluchloralin at 1.68 , profluralin at 1.68 , fluchloralin at 1.12 , profluralin at 1.12 , trifluralin at 1.5 and penoxalin at 1.25 or at 1.5 . Good control of broadleaf weeds was provided by VEL 5052 at 1.0 and at 2.0 and by penoxalin at 1.25 and at 1.5 . The other herbicide treatments gave moderate to satisfactory control of broadleaf weeds.

At 60 days good control of grasses was still observed with the treatments trifluralin at 1.5, profluralin at 1.12, and at 1.68, penoxalin at 1.5, fluchloralin at 1.68 and trifluralin at 0.75 . Good control of broadleaf weeds was provided at 60 days by penoxalin only at 1.5 . Satisfactory control was observed in the plots treated with profluralin at the rates of 1.12 and 1.68 .

Those compounds applied both PPI and as preemergent, generally provided better and more persistant weed control than as preemergent applications only. This was especially noted for U 27267.

Table 4 shows the control values for herbicides applied exclusively as preemergent. The majority of the products controlled annual grasses better than broadleaf weeds. Chloroxuron, chlorbromuron and prometryn gave better control of broadleaf weeds than of grasses. Metribuzin controlled both types of weeds efficiently. 
Excellent control of grasses at 30 days was observed with both rates of metribuzin, diphenamid, alachlor, DCPA and with oryzalin at the rate of 3.0. Good to excellent control was registered in the plots treated with benthiocarb, chloramben, nitrofen at 4.0 , oryzalin at 1.5 , and prometryn at 1.5 .

Good to excellent control of broadleaf weeds at 30 days was obtained even with the lower rates of metribuzin, chloroxuron, chlobromuron, DCPA, oryzalin and prometryn and with alachlor at 3.0, diphenamid at 5.6 , and methazole at 3.36.

TABLE 3.-Weed control percent' (grasses and broadleaves) provided by herbicides applied as PPI or PPI and preemergence treatments in three localities of Puerto Rico, 30 and 60 days after application

\begin{tabular}{|c|c|c|c|c|c|c|}
\hline \multirow{2}{*}{$\begin{array}{l}\text { Common } \\
\text { name }\end{array}$} & \multirow{2}{*}{ Rate } & \multirow{2}{*}{$\begin{array}{l}\text { Time of } \\
\text { application }\end{array}$} & \multicolumn{2}{|c|}{30 days } & \multicolumn{2}{|c|}{60 days } \\
\hline & & & G & $\mathrm{BL}$ & G & BL \\
\hline & $K g a . i / h$ & & & & & \\
\hline Butralin & 1.5 & Pre & 67 & 57 & 60 & 55 \\
\hline Butralin & 2.5 & Pre & 78 & 70 & 63 & 63 \\
\hline Butralin & 1.5 & PPI & 80 & 60 & 68 & 47 \\
\hline Butralin & 2.5 & PPI & 90 & 75 & 73 & 60 \\
\hline Fluchloralin & 1.12 & PPI & 90 & 57 & 70 & 63 \\
\hline Fluchloralin & 1.68 & PPI & 97 & 63 & 75 & 63 \\
\hline Penoxalin & 1.25 & PPI & 85 & 75 & 70 & 65 \\
\hline Penoxalin & 1.5 & PPI & 85 & 78 & 78 & 75 \\
\hline Profluralin & 1.12 & PPI & 88 & 63 & 80 & 70 \\
\hline Profluralin & 1.68 & PPI & 93 & 67 & 80 & 70 \\
\hline Trifluralin & 0.75 & PPI & 72 & 50 & 73 & 55 \\
\hline Trifluralin & 1.5 & PPI & 87 & 63 & 83 & 55 \\
\hline U 27267 & 1.68 & Pre & 57 & 60 & 45 & 53 \\
\hline U 27267 & 3.36 & PPI & 73 & 70 & 62 & 53 \\
\hline U 27267 & 1.68 & Pre & 80 & 62 & 60 & 47 \\
\hline U 27267 & 3.36 & Pre & 93 & 80 & 70 & 53 \\
\hline VEL 5052 & 1.0 & PPI & 65 & 73 & 65 & 55 \\
\hline VEL 5052 & 2.0 & PPI & 65 & 80 & 70 & 55 \\
\hline VEL 5052 & 1.0 & Pre & 68 & 70 & 65 & 45 \\
\hline VEL 5052 & 2.0 & Pre & 80 & 75 & 68 & 48 \\
\hline
\end{tabular}

${ }^{1}$ Means of the values registered in the three localities.

At 60 days, good control of grasses was still present in the plots treated with both rates of oryzalin, metribuzin, diphenamid and alachlor, and also with benthiocarb at 6.0, DCPA at 11.0, and nitrofen at 4.0. Good control of broadleaf weeds up to this time was provided by chloroxuron at 3.36 , chlorbromuron at 2.24 , metribuzin at 0.5 and 0.75 , oryzalin at 3.0 and prometryn at 1.5 .

\section{DISCUSSION}

There were differences in selectivity, degree of weed control and type of weeds controlled among herbicides. The performance of a given her- 
bicide varied with the rate, the time of application and with the locality. There were marked differences in sensitivity of the four crops to a given herbicide and also of a particular crop to herbicides closely related chemically.

Most herbicides that were selective to the four crops gave better control of grasses than of broadleaf weeds. These herbicides performed better in Lajas, where grassy weeds predominated, than in Isabela where broadleaf weeds were more abundant. On the other hand, herbicides that provided

TABLE 4.-Weed control percent' provided by preemergence applied herbicides in three localities of Puerto Rico 30 and 60 days after application

\begin{tabular}{|c|c|c|c|c|c|}
\hline \multirow{2}{*}{ Common name } & \multirow{2}{*}{ Rate } & \multicolumn{2}{|c|}{30 days } & \multicolumn{2}{|c|}{60 days } \\
\hline & & $\mathrm{G}$ & $\mathrm{BL}$ & G & BL \\
\hline & Kg a.i/ha & & & & \\
\hline Alachlor & 1.5 & 92 & 70 & 75 & 53 \\
\hline Alachlor & 3.0 & 97 & 78 & 85 & 55 \\
\hline Benthiocarb & 3.0 & 75 & 48 & 67 & 47 \\
\hline Benthiocarb & 6.0 & 85 & 65 & 80 & 57 \\
\hline Chloramben & 2.0 & 75 & 60 & 43 & 50 \\
\hline Chloramben & 3.0 & 85 & 63 & 63 & 57 \\
\hline Chlorbromuron & 1.12 & 33 & 77 & 43 & 67 \\
\hline Chlorbromuron & 2.24 & 57 & 85 & 50 & 78 \\
\hline Chloroxuron & 1.68 & 37 & 80 & 43 & 68 \\
\hline Chloroxuron & 3.36 & 47 & 87 & 53 & 81 \\
\hline DCPA & 9.0 & 92 & 72 & 68 & 53 \\
\hline DCPA & 11.0 & 97 & 82 & 80 & 60 \\
\hline Diphenamid & 3.36 & 95 & 68 & 78 & 53 \\
\hline Diphenamid & 5.60 & 98 & 78 & 83 & 55 \\
\hline Methazole & 3.36 & 70 & 75 & 60 & 53 \\
\hline Metribuzin & 0.5 & 98 & 97 & 77 & 80 \\
\hline Metribuzin & 0.75 & 98 & 97 & 82 & 90 \\
\hline Nitrofen & 2.4 & 70 & 35 & 63 & 45 \\
\hline Nitrofen & 4.0 & 80 & 55 & 80 & 55 \\
\hline Oryzalin & 1.5 & 88 & 77 & 80 & 67 \\
\hline Oryzalin & 3.0 & 93 & 87 & 90 & 77 \\
\hline Prometryn & 1.0 & 67 & 80 & 50 & 63 \\
\hline Prometryn & 1.5 & 82 & 87 & 60 & 73 \\
\hline
\end{tabular}

${ }^{1}$ Means of the values registered in the three localities.

good control of broadleaf weeds or of both types of weeds, like metribuzin, were more toxic to the crops.

The toxicity of some of the products was more pronounced in Isabela and Fortuna than in Lajas. This difference in phytotoxicity may be related to the degree with which the herbicide moves or is retained by different soils. Differences in mobility of herbicides in the soils where the trials were performed have been observed $(3,4,5)$.

The above-mentioned findings indicate the need of specific herbicide 
recommendations for a given crop, in a particular locality and the importance of considering weed populations and soil characteristics to make such recommendations. It is evident that the availability of compounds to choose from will facilitate the selection of the most convenient treatments for specific situations. Further evaluations of the most promising compounds with each crop in different localities is needed before specific recommendations are made.

\section{RESUMEN}

La acción de 19 herbicidas se evaluó en 50 tratamientos al variar las dosis y las épocas de aplicación, en términos de la fitotoxicidad a los cultivos y el grado de control de malezas gramíneas y latifolias. Se utilizaron seis cultivares de soja, siete de gandul, dos de frijol y dos de habichuela. Los ensayos se efectuaron en las subestaciones de Isabela, Lajas y Fortuna.

Se registraron diferencias notables en el dano causado por susceptibilidad de los cultivos por los mismos herbicidas y en el comportamiento de un mismo cultivo a herbicidas químicamente relacionados. Se registraron variaciones entre localidades en cuanto a la fitotoxicidad y el grado de control ocasionados por una misma dosis de herbicida. Estas diferencias parecen estar asociadas con variaciones en las propiedades de los suelos y las especies y la abundancia de las malezas.

Los resultados de este trabajo resaltan la importancia de tomar en consideración simultáneamente por lo menos los factores cultivo, clase y abundancia de malezas y las características del suelo al recomendar herbicidas, y la de contar con varios productos registrados para uso en un mismo cultivo con el fin de poder seleccionar el más apropiado para situaciones específicas. Los resultados deben ser de utilidad en la selección de tratamientos de herbicidas para estudios más detallados con los cuatro cultivos.

\section{LITERATURE CITED}

I. Hammerton, J. L., 1974. Weed control in soybeans. Proceedings of the workshop in soybeans for tropical and subtropical conditions, INTSOY Series No. 2, 97-108.

2. IPPC, 1974. Experimental Herbicides. Status report by crops. Rep. 74.6, Oreg. State Univ. 53-56.

3. Liu, L. C. and Cibes-Viadé, H., 1968. Influence of soil properties on the phytotoxicity of Atrazine, Ametryne, Prometryne, and Diuron in Puerto Rican soils, J. Agri. Univ. P.R. 52 (4): 269-80.

4. - and — 1970. Leaching of Atrazine, Ametryne and Prometryne in the soil, J. Agri. Univ. P.R. 54 (1): 5-18.

5. - and - 1973, Adsorption of Fluometuron, Prometryne, Sencor and 2,4-D by soils, J. Agri. Univ. P.R. 57 (4): 286-93.

6. Lugo-López, M. A., Juárez, J. and Bonnet, J. A., 1968. Relative infiltration rate of Puerto Rican soils, J. Agri. Univ, P.R. 52 (3): 233-40.

7. Pulver, E., 1974. Control de malezas en soya, Rev. Comalfi, Colombia 1:156-75. 